\title{
AS-SUNNAH SEBAGAI SUMBER HUKUM ISLAM DALAM ERA YANG PROBLEMATIK
}

\author{
Zulham Maula Farid ${ }^{1}$, Yuhana Rizki Farista ${ }^{2}$, \\ Lailatul Qodriyyah ${ }^{3}$
}

Fakultas Syari'ah dan Ilmu Hukum Universitas Islam Negeri Sayyid Ali Rahmatullah (UIN SATU) Tulungangung

Jl. Mayor Sujadi No.46, Kudusan, Plosokandang, Kec. Kedungwaru, Kabupaten Tulungagung, Jawa Timur 66221 | ilaliqoq@gmail.com DOI: https://doi.org/

\begin{abstract}
As-Sunnah or what we often call Sunnah is the plural form of the word sunan which means "habit" or "to be done". At first glance it is similar to the Hadith, but it is different if the sunnah is everything that is quoted from the Prophet, whether in the form of words, practices, or in the form of provisions, teachings, characteristics, behavior, and life journey before the Prophet was appointed as an apostle. Meanwhile the hadith existed after the prophet was appointed as a messenger. There are two more terms that are similar but different, namely Khabar and Atsar. The function of sunnah in the Koran is ta'qid (as reinforcement), tabyin (as an explanation), and mustaqillah. In addition, the relationship between sunnah and Al-Qur'anis like two complementary things between mubayyin and maudhu al bayan, mufashil and maudhu ijmal and between juz'i and kulli.
\end{abstract}

Keywords: Hadith, Sources of Islamic Law, Legal Problems

Abstrak: As-Sunnah atau sering kita sebut dengan Sunnah adalah bentuk plural dari kata sunan yang bermakna "kebiasaan" atau "biasa dilakukan". Sekilas mirip dengan Hadis namun berbeda kalo sunnah itu segala sesuatu yang dinukilkan dari Nabi, baik itu berupa perkataan, perbuatan, ataupun berupa ketetapan, pengajaran, sifat, kelakuan, atau perjalanan hidup sebelum Nabi diangkat menjadi rasul. Sedangkan hadis itu

\section{IJLIL: INDONESIAN JOURNAL OF LAW AND ISLAMIC LAW VOLUME 3 NOMOR 2 JULI-DESEMBER 2021; ISSN 2721-5261 E-SSN 2775-460X}


setelah nabi di angkat menjadi Rasul. Ada dua istilah lagi yang sekilas mirip namun berbeda, namanya Khabar dan Atsar. Fungsi sunnah terhadap Al-Qur'anyaitu ta'qid (sebagai penguat), tabyin (sebagai penjelas), dan mustaqillah. Selain itu hubungan antara sunnah dan Al-Qur'anitu bagaikan dua hal yang saling melengkapi antara mubayyin dan maudhu al bayan, mufashil dan maudhu ijmal dan antara juz'i dan kulli.

Kata Kunci: Hadis, Sumber Hukum Islam, Problematik hukum

\section{Pendahuluan}

Al-Sunnah menjadi salah satu hal yang sering dibicarakan dan dikaji oleh para ahli dalam perkembangan studi Islam bertujuan untuk mengembangkan ilmu tentang sunnah Rasulullah. Al-Sunnah juga merupakan sumber hukum kedua dalam Islam. Selain daripada itu hadis juga sebanding dengan Al-Qur'an tingkat kesakralannya. Meskipun demikian, jika dilihat dari segi sejarahnya yang mengkodifikasian hadis dilakukan setelah Rasulullah wafat bisa menjadi titik lemah bagi agama Islam.

Cara hadis bisa sampai di generasi sampai sekarang adalah dengan cara periwayatan. Perspektif kritik sanad dan periwayatan dalam Al-Qur'an tidak terlalu terlihat, dikarenakan Al-Qur'an diriwayatkan secara terus menerus antar generasi tanpa adanya kesempatan untuk membuat kesepakatan berbohong (mutawatir). Hal ini berbeda dengan periwayatan hadis, periwayatan hadis yang diriwayatkan 
orang per orang sehingga kritik sanad dan periwayatannya begitu terlihat.

\section{Pembahasan}

\section{Pengertian Sunnah, Hadis, Khabar dan Atsar}

Secara sekilas jika kita tanya ke masyarakat awan antara Sunnah, dan Hadis pasti banyak yang akan menjawab jika dua hal itu sama. Pada hal antara Sunnah dan Hadis itu adalah dua hal yang berbeda. Ada juga istilah lain yang jarang di ketahui oleh masyarakat yaitu Khabar dan Atsar. Berikut penjelasan mengenai Sunnah, Hadis, Khabar dan Atsar:

1. Sunnah

Sunnah (سنة sunnah, plural سنن sunan) yaitu kata yang berasal bahasa Arab yang bermakna "kebiasaan" atau "biasa dilakukan". Sunnah juga di artikan sebagai jalan yang ditempuh, baik itu sifatnya mulia atau jelek. Hal ini berdasarkan hadis Nabi, yang menyatakan:

$$
\text { من سن سنة حسنة فله أجرها وأجر من عمل ما إلى يوم القيامة ومن سل }
$$

Artinya:

"Barang siapa mengadakan sesuatu sunnah (jalan) yang baik, maka baginya pahala sunnah itu dan pahala orang lain yang mengerjakannya hingga hari kiamat. Dan barang siapa mengerjakan sesuatu sunnah yang buruk, maka atasnya dosa 
As-Sunnah Sebagai Sumber Hukum Islam Dalam Era Yang Problematik

membuat sunnah buruk itu dan dosa orang yang mengerjakannya hingga hari kiamat" (HR. Muslim)

Sedangkan menurut istilah, sunnah ialah segala sesuatu yang dinukilkan dari Nabi, baik itu berupa perkataan, perbuatan, ataupun berupa ketetapan, pengajaran, sifat, kelakuan, atau perjalanan hidup sebelum Nabi diangkat menjadi rasul. ${ }^{1}$

2. Hadis

Hadis berasal dari kata "al-hadis", jamaknya, "al-ahdis", al-hadisan, dan al-hutsan. Menurut etimologi, kata "al-hadit" meliputi: Al-Jadid, lawan Qadim artinya yang baru (jamaknya hidats, hudatsa, dan hudits), Al-Khabar (berita); dan Al-Qarib (dekat).

Sedangkan menurut istilah yaitu segala ucapan, perbuatan dan segala keadaan atau perilaku Rasulullah SAW. ${ }^{2}$ Adapun tiga kategori hadis yaitu: Perkataan (Qauliyah), Perbuatan (fi'liyah), atau Keadaan (ahwaliyah).

3. Khabar

Khabar (الخبر) secara etimologi yaitu An-Naba' (أنبأ) yang berarti warta atau berita. Para ulama' berpendapat jika Khabar adalah bentuk sinonim dari Hadis. Namun, Khabar ini lebih umum.

1 Ramli Abdul Wahid, Studi Ilmu Hadis, Cet. III (Bandung; Citapustaka Media Perintis, 2011), hal. 5.

${ }^{2}$ Mahmud, At-Thahha, Ushul al Takhrij wa Dirasatu al Asaanid (Riadh: Maktabah al-Rusydi, 1983), hal. 155. 
Maka dapat disimpulkan khabar ialah segala sesuatu yang disandarkan kepada Rasulullah SAW dan juga kepada selain Rasulullah. ${ }^{3}$

4. Atsar

Secara etimologi atsar bermana sisa dari sesuatu, atau jejak. Dan secara terminologi, atsar adalah:

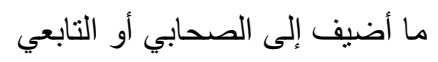

Segala sesuatu yang disandarkan pada sahabat atau tabi'in. ${ }^{4}$

Namun terkadang atsar juga didefinisikan sebagai segala sesuatu yang disandarkan kepada Nabi SAW.

Contohnya:

$$
\text { وفي الأثر عن البي صلى الله عليه وسلم }
$$

Dalam sebuah atsar dari NabiS AW...

Eksistensi Sunnah sebagai sabda Nabi dan fungsinya terhadap Al-Qur'an

Al-Qur'an merupakan sumber ajaran Islam yang paling utama dan dijamin baik secara kebenaran, keutuhan, atau kemurniannya selain makna dari Al-Qur'an banyak yang masih bersifat mujmal (Global) maka diperlukan penjelasan dari makna dari Al-Qur'anagar bisa ditafsirkan terutama terhadap beberapa hukum di Al-Qur'an yang masih universal.

3 Shalih Al Utsaimin, Mustholah Al Hadits, (Kairo: Maktabah Ilmi, 1994), hlm. 5 .

4 Ibid. 
Saat Rasulullah SAW masih hidup dulu setiap ada suatu permasalahan para sahabat bisa langsung menanyakan nya kepada Nabi Rasulullah SAW. Selain itu, Sunnah termasuk salah satu sumber hukum Islam setetalah Al-Qur'an. Hal ini karena Al-Qur'an bersifat qhat'i al wurud, sedangkan sunnah bersifat dhanni al wurud.

Adapun fungsi sunnah yaitu ta'qid (sebagai penguat) AlQur'an. Kedua, tabyin (sebagai penjelas) Al-Qur'an dan yang terakhir, sunnah sebagai mustaqillah, mendefinisikan hukum yang belum ada hukumnya dalam Al-Qur'an.

Sunnah dan Al-Qur'an adalah dua hal yang saling melengkapi dan tak terpisahkan antara mubayyin dan maudhu al bayan, mufashil dan maudhu ijmal dan antara juz'i dan kulli. $^{5}$

\section{Kodifikasi Hadis}

Kodifikasi atau tadwin dalam bahwa arab memiliki arti menghimpun, mengumpulkan atau membukukan. Jadi yang dimaksud kodifikasi hadis ialah mengumpulkan tulisantulisan hadis Nabi Muhammad ke dalam mushaf. Dalam kegiatan pengumpulan hadis setiap ulama ahli hadis melakukan nya secara mandiri. Karena akan menimbulkan banyak kendala jika dalam proses pengumpulan ini dilakukan

\footnotetext{
5 Moh. Turmudi, Jurnal Pemikiran Keislaman, Vol 27, No 1 (Kediri: Institut Agama Islam Tribakti (IAIT), 2017).
} 
dengan membentuk sebuah kelompok. Hal ini terjadi dikarenakan cukup banyak dan tersebarnya jumlah periwayat hadis.

Kodifikasi hadis terbagi menjadi dua masa, pertama kodifikasi al-syakhshiy ialah kodifikasi pribadi dimulai sejak masa Rasulullah dan belum resmi menjadi kebijakan pemerintah. Kedua kodifikasi al-rasmiy ialah kodifikasi resmi dimulai pada masa Umar ibn Abdul Aziz dan sudah resmi menjadi kebijakan pemerintah.

Periwayatan hadis pada zaman Rasulullah lebih cenderung menggunakan lisan dibandingkan menggunakan tulisan. Ini dikarenakan jumlah sahabat yang tidak bisa menulis jauh lebih banyak daripada sahabat yang bisa menulis. Selain itu orang Arab juga lebih senang untuk menghafalkannya. Ketika Rasulullah masih hidup, penyampaian hadis kepada para sahabat dilakukan dengan cara diucapkan (didiktekan). Rasulullah juga melarang para sahabat untuk menuliskannya. Hal ini dilakukan untuk menjaga supaya tulisan hadis tidak bercampur dengan tulisan Al-Qur'an.

Kodifikasi hadis resmi terjadi pada masa Khalifah Umar ibn Abdul Aziz dengan diterbitkannya surat perintah penghimpunan hadis. Penyebaran Agama Islam yang semakin meluas hingga keluar dari jazirah Arab menimbulkan semakin banyak ragam dari permasalahan yang terjadi dalam 
masyarakat, hal ini tentu membutuhkan petunjuk dari hadis Rasulullah selain dari Al-Qur'an untuk pemecahan masalah yang ada. Selain itu mulai terpencarnya para sahabat ke berbagai wilayah, meninggalnya para sahabat baik karena faktor usia maupun gugur dalam medan perang, mulai muncul dan berkembangnya hadis-hadis palsu, juga AlQur'an yang sudah dikodifikasi sehingga tidak perlu lagi takut akan tercampur antara hadis dan Al-Qur'an. Mendorong Khalifah Umar ibn Abdul Aziz untuk melakukan kodifikasi hadis.

\section{Klasifikasi Hadis Ditinjau dari Kuantitas Sanad}

Jumhur ulama telah memecah hadis menjadi dua buah bagian: pertama, hadis yang tidak memiliki batasan jumlah dalam sanad (periwayatan), yaitu hadis mutawatir. Kedua, hadis yang memiliki batasan jumlah tertentu dalam sanad (periwayatan), yaitu hadis ahad. Sedangkan ada juga sebagian lain yang memecah nya menjadi tiga bagian, diantarnya adalah hadis mansyur, hadis ahad, dan hadis mutawatir. Tetapi perbedaan ini tidak mendasar karena yang berbeda hanya pandangan penempatan hadis masyhur berdiri sendiri dan satunya lagi dimasukkan kedalam bagian hadis ahad.

1. Hadis Mutawatir

Hadis mutawatir merupakan hadis yang diriwayatkan oleh banyak orang yang tidak mungkin mereka sepakat untuk berbohong dari awal sanad sampai akhir sanad nya. Adapun 
syarat sebuah hadis dikatakan sebagai hadis mutawatir sebagai berikut: diriwayatkan oleh banyak perawi (periwayat hadis), hadis tersebut harus lah hasil penangkapan panca indera sendiri, adanya kesamaan jumlah sanad dalam setiap tingkatannya, tercapainya batas tertentu jumlah perawi sehingga tidak mungkin bagi mereka bersepakat untuk berbohong. Hadis mutawatir dibagi menjadi dua jenis, hadis mutawatir lafdzy, yakni hadis yang diriwayatkan dengan kesesuaian lafadz-nya dan hadis mutawatir ma'nawiy adalah hadis yang diriwayatkan dengan kesesuaian makna.

2. Hadis Ahad

Hadis ahad merupakan hadis yang tidak memenuhi persyaratan dari hadis mutawatir misalnya diriwayatkan oleh satu, dua, tiga dan seterusnya perawi dengan jumlah yang tidak sampai seperti hadis mutawatir. Hadis ahad dibagi menjadi tiga jenis,pertama hadis masyhur adalah yang diriwayatkan oleh tiga orang dalam setiap tingkatanya tetapi tidak mencapai hadis mutawatir. Kedua hadis aziz adalah hadis yang diriwayatkan oleh dua orang dalam setiap tingkatan nya. Ketiga hadis gharib adalah hadis yang diriwayatkan oleh satu orang saja dalam setiap tingkatan nya. Klasifikasi Sunnah Ditinjau dari Kualitas Sanad (Shahih, Hasan dan Dha'if)

Sebelum ke ranah pembahasan pada pembagian atau pengelompokkan. Hadis dilihat dari segi kualitas dan 
As-Sunnah Sebagai Sumber Hukum Islam Dalam Era Yang Problematik

kuantitas sanadnya yang telah shahih, hasan, dan dha'if (dhaif dari sudut perawinya serta kehujahan hadis shahih dan hadis hasan).

A. Hadis Shahih

1. Pengertian Hadis Shahih

Menurut bahasa, shahih diambil dari istilah shahha, yashihhu, suhhan wa shihhatan wa shahahan, yang arti nya, yang sehat, yang selamat, yang benar, yang sah dan yang benar. Pendapat para ulama biasa menyebut istilah shahih itu menjadi anonim dari kata saqim (sakit). Maka hadis shahih menurut bahasa berarti hadis yang sah, hadis yang sehat atau hadis yang selamat. Hadis Shahih didefinisikan oleh Ibnu Ash Shalah, sebagai berikut: "Hadis yang disandarkan kepada Nabi saw yang sanadnya bersambung, diriwayatkan oleh (perawi) yang adil dan dhabit hingga sampai akhir sanad, tidak ada kejanggalan dan tidak ber "illat".

Dari kedua pengertian di atas maka bisa difahami bahwa hadis shahih adalah hadis yang disandarkan kepada Nabi Muhammad SAW. Sanadnya bersambung, perawinya yang adil, kuat ingatannya atau kecerdasannya, tidak ada cacat atau rusak.

2. Syarat-Syarat Hadis Shohih

Menurut ta'rif muhadditsin, maka dapat difahami bahwasuatu hadis dapat dikatakan shahih, apabila telah memenuhi lima syarat: 
a. Sanadnya bersambung

Yang dimaksud sanad bersambung adalah tiaptiapperiwayatan dalam sanad hadis menerima periwayat hadisdari periwayat terdekat sebelumnya, keadaan ini berlangsung demikian hingga akhir sanad dari hadis itu.

b. Periwayatan bersifat adil

Adil di sini adalah periwayat seorang muslim yang baligh,berakal sehat, selalu memelihara perbutan taat danmenjauhkan diridari perbuatan - perbuatan maksiat.

c. Periwayatan bersifat dhabit

Dhabit merupakan orang yang kuat hafalannya tentang apa yang sudah didengarnya dan mampu mengungkapkan hafalannyakapan saja ia menghendakinya.

d. Tidak Janggal atau Syadz

Adalah hadis yang tidak bertentangan dengan hadis lainyang sudahdiketahui tinggi kualitas ke-shahih-annya.

e. Terhindar dari illat (cacat)

Adalah hadis yang tidak memiliki cacat, yang disebabkan adanya hal yang tidak baik, yang kelihatannya samar-samar.

3. Kehujjahan Hadis Shahih

Para Ulama sependapat bahwa hadis ahad yang shahih dapat dijadikan hujjah untuk menetapkan syariat islam, namun mereka tidak selaras dengan pendapat masingmasing. Jika hadis kategori ini dijadikan untuk menetapkan soal-soal aqidah. Perbedaan di atas berpangkal pada 
perbedaan penilaian mereka tentang faedah yang diperoleh dari hadis ahad yang shahih, yaitu apakah hadis semacam itu member faedah qoth'i sebagaimana hadis mutawatir, maka hadis-hadis tersebut dapat dijadikan hujjah untuk menetapkan masalah-masalah aqidah. Akan tetapi, yang menganggap hanya member faidah zhanni, berarti hadishadis tersebut tidak dapat dijadikan hujjah untuk menetapkan soal ini.

B. Hadis Hasan

1. Pengertian Hadis Hasan

Menurut pendapat Ibnu Hajar, "Hadis hasan adalah hadis yang dinukilkan oleh orang yang adil, yang kurang kuat ingatannya, yang muttasil sanadnya, tidak cacat dan tidak ganjil." Imam Tirmidzi mengartikan hadis hasan sebagai berikut: “Tiap-tiap hadis yang pada sanadnya tidak terdapat perawiyang tertuduh dusta (pada matan-nya) tidak ada kejanggalan (syadz) dan (hadis tersebut) diriwayatkan pula melalui jalan lain.”7 Dari uraian di atas, maka dapat difahami bahwa hadis hasan tidak mengkategorikan kelemahan dalam sanadnya kurang kesempurnaan hafalannya. Di samping itu, hadis hasan hampir sama dengan hadis shahih, perbedaannya

${ }^{6}$ Zufran Raman, Kajian Sunnah Nabi SAW Sebagai Sumber Hukum Islam, Pedoman Ilmu Jaya, Cet- Ke-1, Jakarta, 1995, hal. 40 7At-Tirmidzi, Sunan At-Tirmidzi, Dar Al-Fikr, Bairut, 1980, hal.76 
hanya mengenai hafalan, yang hadis hasan rawinya tidak kuat hafalannya.

2. Syarat-Syarat Hadis Hasan

Adapun syarat-syarat yang harus dipenuhi bagi suatu hadis yang dikategorikan sebagai hadis hasan, yaitu:

a. Para perawinya yang adil,

b. Ke-Dhabith-an perawinya dibawah perawi Hadis shahih,

c. Sanad-sanadnya bersambung,

d. Tidak terdapat kejanggalan atau syadz,

e. Tidak mengandung 'illat.

C. Kehujjahan Hadis Hasan

Kehujjahan hadis hasan, Sebagaimana Hadis Shahih, menurut para ulama ahli hadis, bahwa hadis hasan, baik hasan Li-dzatihi maupun hasan Li-Ghairihi, juga dapat dijadikan hujjah untuk menetapkan suatu hukum, harus diamalkan. Hanya saja terdapat perbedaan pandangan diantara mereka dalam soal penempatan rutbah (urutannya), yang disebabkan oleh kualitasnya masing-masing.

D. Hadis Dhaif

1. Pengertian Hadis Dhaif

Kata Dhaif menurut bahasa yang berarti lemah, sebagai lawan dari Qawiy yang kuat. Sebagai lawan dari kata shahih, kata Dhaif secara bahasa berarti Hadis yang lemah, 
yang sakitatau yang tidak kuat. ${ }^{8}$ Secara Terminilogi, para ulama mendefinisikan secara berbeda-beda. Akan tetapi pada dasarnya mengandung maksud yang sama, pendapat AnNawawi : "Hadis yang di dalamnya tidak terdapat syaratsyarat Hadis Shahih dan syarat-syarat Hadis Hasan."9

2. Berhujjah dengan Hadis Dhaif

Para ulama sepakat melarang meriwayatkan hadis dhaif bukan maudhu. Ada pun hadis dhaif bukan hadis maudhu ${ }^{e e}$ maka diperselisihkan tentang boleh atau tidaknya diriwayatkan untuk berhujjah. Dalam hal ini ada beberapa pendapat:

a. Melarang secara mutlak

b. Membolehkan Ibnu Hajar Al-Asqalani, ulama hadis yang memeperbolehkan berhujjah dengan hadis dhaif untuk keutamaan amal, memberikan 3 syarat:

1. Hadis Dhaif itu tidak keterlaluan.

2. Dasar Amal yang ditunjukan oleh hadis dhaif tersebut, masih dibawah suatu dasar yang dibenarkan oleh hadis yang dapat diamalkan (Shahih atau Hasan)

3. Dalam mengamalkannya tidak mengitikadkan bahwa hadis tersebut benar-benar bersumber dari Nabi. Tetapi tujuan ikhtiyath (hati-hati) belaka dari

\footnotetext{
${ }^{8}$ Utang Ranuwijaya, Op.Cit., hal. 176

${ }^{9}$ An-Nawaawi, At-Taqrib Li An-Nawawi Fann Ushul Al-Hadist, Abd Rahman Muhammad Kairo, tt, 19.
} 
As-Sunnah Sebagai Sumber Hukum Islam Dalam Era Yang Problematik

beberapa uraian diatas maka dapat disimpulkan bahwa apabila menggunakan hadis dhaif untuk dijadikan suatu sugesti amalan maka dapatlah kita pergunakan hal ini memotivasi bagi masyarakat. Untuk memperbanyak amalan-amalannya, hadis yang diterangkan harus selektif mungkin juga sampai tidak masuk akal atau rasional.

\section{Kehujahan Sunnah Sebagai Sumber Istimbat Hukum dalam Era Modern Yang Problematik}

Kehujjaan As-Sunnah sebagai sumber Istimbat hukum berada di posisi kedua setelah Al-Quran. Sunnah sebagai sumber hukum Islam terbagi dari 3 (tiga) macam yaitu: pertama, sunnah Qauliyah (perkataan nabi) yaitu hadis Rasul yang disampaikan Rasulullah dan biasanya berhubungan dengan Aqidah-Akhlak atau yang lainnya. Kedua, sunnah Fi'liyah (perbuatan nabi) yaitu segala bentuk tingkah laku yang dilakukan nabi untuk diikuti dan di taati oleh umatnya hingga akhir zaman. Terakhir, ketiga, yaitu sunnah Tagririyah merupakan sunnah ketika ada seseorang melakukan sesuatu perbuatan dan bertanya suatu ucapan kepada nabi. Namun nabi diam dan tidak menyangga nya maka hal itu adalah pengakuan nabi.

Pada dasarnya, dari 3 (tiga) poin dasar berkaitan dengan kehujjahan As-Sunnah; merupakan pondasi dasar dalam menggali hukum-hukum modern dengan landasan 
hukum Islam di samping keberadaan Al-Quran sebagai sumber hukum utama. Problematik hukum di era modern dapat diselesaikan dengan baik melalui peraturan-peraturan hukum yang ada, utamanya yang berlandaskan pada 3 (tiga) nilai utama As-Sunnah tersebut.

\section{Kesimpulan}

Sunnah difungsikan sebagai hujjah dalam mengistinbatkan beberapa hukum Islam yang salah satunya yaitu sunnah Qauliyah (perkataan Nabi) merupakan hadis Rasul yang pernah belaiau ungkapkan di berbagai dakwah aqidahnya. Di samping itu, keberadaan As-Sunnah menjadi petunjuk untuk umat Islam dalam menjalankan aktivitas hidupnya sehari-hari, baik secara individua atau kelompok.

\section{Daftar Pustaka}

Abdillah, Mujiyono, Dialektika Hukum Islam $\mathcal{E}$ Perubahan Sosial, Surakarta: UM, 2003.

Agus Sholahuddin dan Agus Suyadi, Ulumul Hadis, Bandung: Pustaka Setia, 2001.

Al-Albani, Muhammad Nashiruddin, Shahih Sunan Tirmidzi: Seleksi Hadis Shahih dari Kitab Sunan Tirmidzi, Buku I. Jakarta: Pustaka Azzam. 2006 At-Tirmidzi, Sunan At-Tirmidzi, Dar Al-Fikr, Bairut, 1980. 
As-Sunnah Sebagai Sumber Hukum Islam Dalam Era Yang Problematik

Effendi, Satria. M. Zein. Metodologi Hukum Islam dalam Amrullah Ahmad dkk. Dimensi Hukum Islam dalam Sistem Hukum Nasional Jakarta: Gema Insani Press. 1996.

Mahmud, At-Thahha, Ushul al Takhrij wa Dirasatu al Asaanid.

Riyadh: Maktabah al-Rusydi, 1983.

Moh. Turmudi , Jurnal Pemikiran Keislaman. Vol 27, No 1.

Kediri: Institut Agama Islam Tribakti (IAIT), 2017.

Nur ad-Din, Manhaj Naqd fi 'Ulūm Al-Hadīś, Damaskus: Dar al-Fikr, 1979.

Ramli Abdul Wahid, Studi Ilmu Hadis, Cet. III. Bandung; Citapustaka Media Perintis, 2011.

Shalih Al Utsaimin, Mustholah Al Hadis. Kairo: Maktabah Ilmi, 1994.

T.M. Hasbi Ash-Shiedieqy, Sejarah Pengantar Ilmu Hadis, Jakarta: Bulan Bintang, 1988.

Zufran Raman, Kajian Sunnah Nabi SAW Sebagai SumberHukum Islam, Pedoman Ilmu Jaya, Cet- Ke-1, Jakarta, 1995. 
As-Sunnah Sebagai Sumber Hukum Islam Dalam Era Yang Problematik

Zuhad, Metode Pemahaman Hadis Mukhtalif dan Asbāb al-Wurūd, Semarang: Rasail Media Group, 2011. 